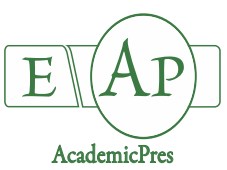

Karaozan A et al. $(2020)$
Notulae Botanicae Horti Agrobotanici Cluj-Napoca 48(4):1862-1872
DOI: $10.15835 /$ nbha48411985
Research Article

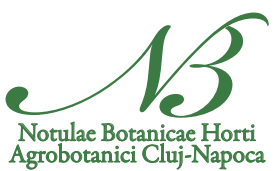

\title{
Concurrent detection of five Yellow dwarf viruses (B/CYDVs) in wheat in Mardin (Turkey) and phylogenetic relationship of BYDV-PAV
}

\author{
Abdulselam KARAOZAN, Mustafa USTA*, \\ ${ }^{1}$ Van Yuzuncu Yil University, Faculty of Agriculture, Department of Plant Protection, Van, Turkey; abdsImkrzn@gmail.com \\ (*corresponding author); ustamustafa07@gmail.com
}

\begin{abstract}
Wheat (Triticum aestivum L.) is a natural host of many viruses. Yellow dwarf viruses belonging to the Luteoviridae family are important virus species that cause economic loss by restricting wheat production worldwide. Surveys were conducted in 2017 to determine Yellow dwarf viruses (BYDV-PAV, BYDV-MAV, BYDV-SGV, BYDV-RMV, and CYDV-RPV) and their infection rates in wheat production areas in Mardin province. 400 fresh leaf samples collected were tested by Multiplex reverse transcription-polymerase chain reaction (m-RT-PCR). The overall infection rate was found to be 3\%. BYDV-PAV has been identified as the most widespread virus with a $2.5 \%$ presence rate. It was found out that BYDV-SGV, CYDV-RPV, and BYDVRMV infections were lower, with rates of $1.75 \%, 0.5 \%$ and $0.25 \%$ respectively. In the current study, double infections were detected in 8 samples. The overall infection rate of the detected viruses (BYDV-PAV, BYDVSGV, CYDV-RPV, BYDV-RMV) was found to be lower than the records reported in previous similar studies. No BYDV-MAV infection was found in any of the wheat samples tested. The cDNA of the coat protein (CP) gene of a BYDV-PAV isolate randomly selected from virus-positive samples was cloned, bidirectionally sequenced, and the phylogenetic relationship revealed. According to the phylogenetic analysis with 19 different isolates in the NCBI database of BYDV-PAV Mardin isolate, it showed the highest genetic similarity by 95.52\% with the Germany isolate (KY634926) while the lowest similarity rate was $89.22 \%$ with the Germany and Pakistan isolates (KY634886 and JQ811489). The presence of BYDV-PAV, BYDV-SGV, CYDV-RPV, and BYDV-RMV were reported for the first time with this survey study conducted in Mardin.
\end{abstract}

Keywords: cloning; mardin; molecular characterization; multiplex RT-PCR; survey; wheat

\section{Introduction}

Wheat, grown in a wide geography and climate at the present time, is one of the first plants to be cultivated and its history goes back to 10,000 years ago (Kün, 1996; Ilbağı, 2003; Anonim, 1996). Wheat, a member of the Poaceae family, is the most important cultivated plant after corn. In world's wheat production, EU countries rank first with a $23 \%$ share, China comes second with $19 \%$ and India ranks third with $15 \%$ (FAO, 2018). 
Compared to other crops, wheat production (\%38.1) outweighs in Turkey. The Central Anatolia Region ranks first in wheat production (32\%) followed by the Marmara Region (18\%) and the Southeastern Anatolia Region (15\%). Located in the Southeastern Anatolia region, Mardin is the sixth of the most wheat producing provinces in Turkey with a 3.87\% rate and 833.009 tonnes of wheat production (TUIK, 2018).

Wheat is often negatively affected by viral diseases as well as abiotic factors, fungal and bacterial pathogens. An effective chemical treatment method for viruses that cause significant economic losses is still unknown (Ilbağı, 2017). Viruses in barley yellow dwarf group (BYDVs), which are among the top 4 viruses that cause the highest yield loss in wheat, are the pathogens that cause serious product losses worldwide every year (Rybicki, 2014). BYDVs infection in wheat -though confused with abiotic factors- can cause spotting, yellowing, reddish leaves, rosetting, loss of green color, dwarfing, and necrosis in the wheat. It is also possible to notice severe symptoms in the wheat due to the synergistic effect of the existing two or multiple infections (Erkan ve Yilmaz, 2009).

The Luteoviridae family, which encompasses wheat viruses, has three genera, Luteovirus, Polerovirus and Enamovirus. BYDVs are a member of Luteovirus while CYDVs are a member of Polerovirus genus (Domier, 2012; Sathees, 2015). BYDVs were first identified in barley in 1950 and then their presence in cereals such as wheat, oats, rice, and corn was reported later (Oswald and Houston, 1951; Chain et al., 2006). BYDV viruses with a genome consisting of a single strand (+) RNA have isometric particles of $25-28 \mathrm{~nm}$ in diameter. BYDV viruses are concentrated in the nucleus, cytoplasm, and parenchyma cells in most cases (Domier, 2008; Hogenhout et al., 2008). Viruses in this group (PAV, SGV, RPV, MAV, and RMV) were previously named to be specific to their vector and were then considered five different species, taking into account their genomic characteristics (Gray et al., 1998; Uzunoğulları ve Gümüş, 2017). However, the genomic RNA of the virus identified as Barley yellow dwarf virus-RMV was performed with 5612 nucleotide sequence analysis and it was proposed that its name would be changed to Maize yellof $d$ warf virus-RMV and be classified in the genus Polerovirus (Krueger et al., 2013).

Unlike other viruses that are transported by mechanical means, pollen, contact, and seeds, BYDVs are transmitted only by aphids in a persistent manner. Although it is reported to be carried by about 25 aphids, in most cases Rhopalosiphum padi, Macrosiphum (Sitobion) avenae, Schizaphis graminum, Rhopalosiphum maidis, Acrosternum hilare vectors are the primary important (Deligöz et al., 2011; Siddiqui et al., 2011).

B/CYDV sare the most common group of viruses in Poaceae family plants studied extensively in many continents and countries on a global scale. The presence of these viruses have been reported in some countries like Brazil (Parizoto et al., 2013), Australia (Nancarrow et al., 2014), Pakistan (Siddiqui et al., 2011), Iraq (ElMuadhidi et al., 2001), Tunisia (Hamdi et al., 2020), İran (Rastgou et al., 2005), Hungary (Áy et al., 2008), England/UK (Kendall et al., 1996), China (Tao et al., 2012), Southern Iran (Pakdel et al., 2010), Latvia (Bisnieks et al. 2004), Turkey (Usta et al., 2020; Hassan et al., 2018; Ilbagi et al., 2019), Chech Republic and Sweden (Pokorny, 2006), and Bulgaria (Bakardjeiva et al., 2006).

In Turkey there have been numerous reports about the presence of BYDVs in cereals. However, the studies concerning the South-Eastern Anatolia region is limited. In this study, B/CYDVs causing infections in wheat fields were screened using the m-RT-PCR method and revealed the infection rates in Mardin province. In addition, the genetic diversity of the CP gene of detected BYDV-PAV isolate was investigated.

\section{Materials and Methods}

\section{Survey and virus source}

In April and May 2017, seventy-four fields from seven different geographical regions of Mardin province were surveyed and 400 wheat leaf samples were collected randomly, with at least 5 fresh leaf samples from each field. The collected samples were stored at $-20^{\circ} \mathrm{C}$ until total RNA extraction. 


\section{Total RNA isolation, primers, and cDNA synthesis}

Total RNA isolation was achieved by making minor modifications in the silica-based method reported by Foissac et al. (2001). In cDNA synthesis, Universal Yan Reverse primer (Malmstrom and Shu, 2004) and RevertAid First Strand cDNA kit (Thermo-Fermantas, Vilnius, Lithuania) were used to detect all of BYDVs. Resulted cDNAs were kept in deep-freeze until use.

\section{Detection of $B / C Y D V$ s by multiplex $R T-P C R$ and $R T-P C R$ assays}

To ensure the separation of Group1 (BYDV-PAV, MAV, SGV) and Group2 (CYDV-RPV, BYDVRMV), temperature cycles and primers that give $832 \mathrm{bp}$ and $372 \mathrm{bp}$ fragments, respectively, in PCR tests were adjusted as defined by Malmstrom and Shu (2004). The more precise detection was accomplished using groupspecific primers described by Malmstrom and Shu (2004), Deb and Anderson (2008) and Usta et al. (2020) on group-positive samples.

The $50 \mu \mathrm{l}$ of PCR-mix contained of $31.6 \mu \mathrm{l}$ of RNase free water, $5 \mu \mathrm{l}$ of 10X PCR Buffer, $3 \mu \mathrm{l}$ of $25 \mathrm{mM}$ $\mathrm{MgCl}_{2}, 1 \mu \mathrm{l}$ of $10 \mathrm{mM}$ dNTP, $1 \mu \mathrm{l}$ of $20 \mu \mathrm{M}$ of each primer sets (Shu-F, Yan R, S2a-F, S2b-F), $0.4 \mu \mathrm{l}$ of Dream Taq DNA polymerase enzyme ( $5 \mathrm{U} / \mu \mathrm{l})$ (Thermo Scientific), and $5 \mu \mathrm{L}$ of cDNA. During PCR tests, Yellow dwarf virus isolates previously determined by Usta et al. (2020) were used as positive control and healthy wheat leaves were used as a negative control. PCR products were electrophoresed on the EtBr-added 1\% agarose gel and visualized in the gel imaging and analysis system (Syngene $e^{\mathrm{mt}}$ UV Transilluminator).

\section{Molecular cloning, sequencing, phylogenetic analysis of BYDV-PAV isolate}

Among the viruses detected, the complete CP gene of BYDV-PAV, CYDV-RPV, and the partial CP gene of BYDV-SGV and BYDV-RMV were successfully introduced to the appropriate cloning vector and their nucleotide sequences were determined and submitted in the GenBank. The specific primers used to amplify the complete or partial CP genes were adopted as reported by various researchers (Deb and Anderson, 2008; Usta et al., 2020). Temperature cycles and PCR parameters described by Malmstrom and Shu (2004) were used to amplify related genes of viruses. The amplified DNA fragments were purified from agarose gel (Thermo Scientific) and cloned into the prokaryotic cloning vector (pGEM T-Easy vector, Promega) and transformed into competent bacteria $E$. coli (JM109 strain) cells. Recombinant plasmids were purified from transformed bacteria (GeneJET Plasmid Miniprep Kit, Thermo Scientific) and bidirectional sequencing was performed by a commercial firm (Sentebiolab, Bilkent-ANKARA). Sequence information for each viral genome was stored in GenBank (NCBI).

The phylogenetic relationship and nucleotide similarity of BYDV-PAV sequence with other world isolates were analysed using CLC Main Workbench program (version 6.7.1). For better branching of phylogenetic tree, Zucchini yellow mosaic virus (ZYMV) (JF792368) isolate was chosen as an out-group.

\section{Results}

\section{Field observations and infection rates in 2017}

A survey was carried out in Mardin province to identify Yellow dwarf viruses (BYDV-PAV, -SGV,MAV, -RMV and CYDV-RPV). During the survey, wheat plants showing typical signs of viral infection, such as reddish colour of flag leaves, dwarfing, and chlorotic strip patterns on leaves, were observed (Figure 1).

As seen in Figure 2 (Panel A), DNA fragments (832 bp and $372 \mathrm{bp}$ ) were obtained in the m-RT-PCR test performed with the primers reported by Malmstrom and Shu (2004) indicating that associated samples were infected with one or more viruses. Species-specific primers provided species discrimination of B/CYDVs. The performed tests confirmed that there were BYDV-PAV ( $\approx 600 \mathrm{bp})$, BYDV-SGV $(\approx 254 \mathrm{bp})$, CYDV-RPV $(\approx 615 \mathrm{bp})$ and BYDV-RMV ( $\approx 365 \mathrm{bp})$ in the samples collected. (Figure 2, Panel B, C, D, E). PCR tests produced neither healthy wheat plants nor any fragments belonging to the genome of BYDV-MAV. 
B/CYDV-positive reactions were detected in 12 (3\%) of 400 samples in Mardin province. The highest infection rate was determined in the Nusaybin region and the lowest was in the Artuklu region. The most common virus was BYDV-PAV with a rate of $2.5 \%$ (10 samples), followed by BYDV-SGV, CYDV-RPV, and BYDV-RMV with an infection rate of $1.75 \%$ (7 samples), $0.5 \%$ ( 2 samples) and $0.25 \%$ ( 1 sample), respectively. Furthermore, double infections were determined that containing PAV+SGV (1.75\%) in 7 samples and $\mathrm{PAV}+\mathrm{RPV}(0.25 \%)$ in 1 sample. Multiple virus infections containing more than two viruses were not detected. The overall status of virus infections in wheat samples in the province of Mardin on a regional basis is given in Table 1.
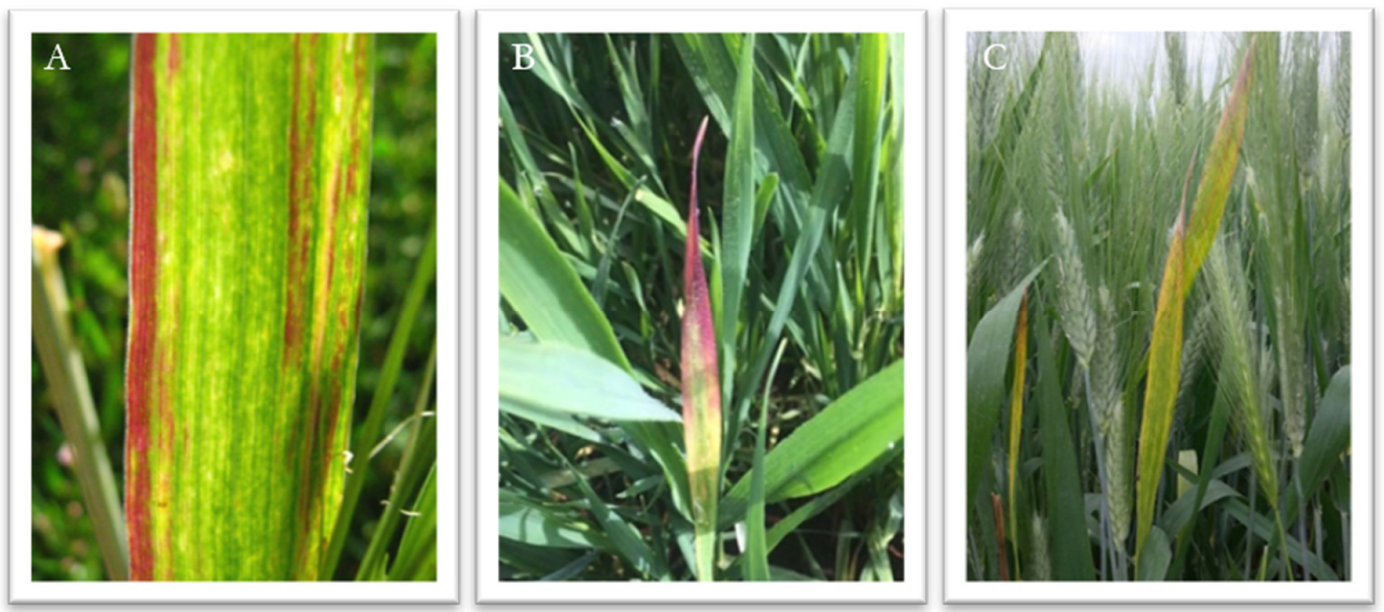

Figure 1. Symptomatic wheat samples in surveys in wheat planting areas of Mardin province Flag leaf redness (A), Chlorotic striped patterns and dwarfing in the early period $(B, C)$

Table 1. Surveyed regions in Mardin province, the number of samples tested and the distribution of detected viruses

\begin{tabular}{|c|c|c|c|c|c|c|c|c|}
\hline \multicolumn{9}{|c|}{ B/CYDV - Positive samples } \\
\hline District & Samples & PAV & SGV & RPV & PAV+SGV & PAV+RPV & RMV & $\%$ \\
\hline Kizıltepe & 170 & 4 & 2 & 1 & 2 & 1 & 1 & 2.95 \\
\hline Derik & 75 & 2 & 2 & - & 2 & - & - & 2.5 \\
\hline Artuklu & 45 & 1 & 1 & - & 1 & - & - & 2.22 \\
\hline Nusaybin & 40 & 2 & 2 & 1 & 2 & - & - & 7.5 \\
\hline Savur & 30 & 1 & - & - & 1 & - & - & 3.33 \\
\hline Dargeçit & 25 & - & - & - & - & - & - & - \\
\hline Midyat & 15 & -- & - & - & - & - & - & - \\
\hline Total & 400 & 10 & 7 & 2 & 7 & 1 & 1 & 3.0 \\
\hline
\end{tabular}



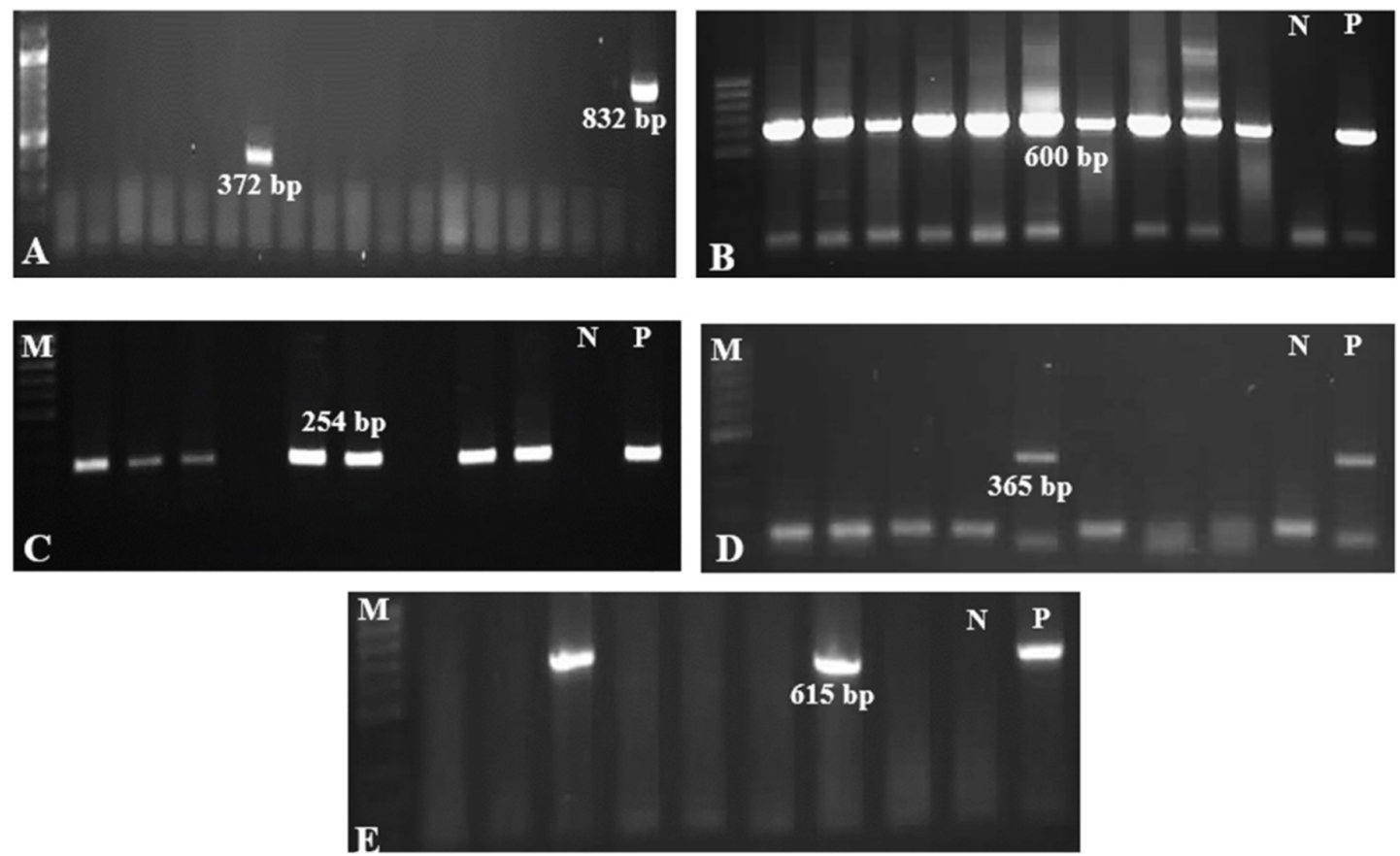

Figure 2. Panel A: Agarose gel image of $m-R T-P C R$ test performed with detection primers in Mardin leaf samples; Positive samples associated with Group2 (372 bp) and Group1 (832 bp); Panel B: Determination of BYDV-PAV with specific primers; Panel C: Determination of BYDV-SGV with the primers of Deb and Anderson (2008); Panel D: Agarose gel image showing the determination of BYDV-RMV with specific primers; Panel E: Agarose gel image showing the determination of CYDV-RPV with specific primers, N: Negative control, P: Positive control, M: 1000 bp DNA ladder

\section{Bioinformatic analysis and phylogenetic relationship of $B Y D V-P A V$}

Partial or complete CP genes of a randomly selected isolate from BYDV-PAV, CYDV-RPV, BYDVSGV and BYDV-RMV were successfully cloned and sequenced. The nucleotide sequence data of BYDV-PAV, CYDV-RPV, BYDV-SGV and BYDV-RMV were deposited in the GenBank with accession numbers MK732034, MK732035, MK940529 and MK955886 respectively. It was revealed that the CP gene of the BYDV-PAV and CYDV-RPV were 603 bp and 615 bp, respectively, while the partial CP gene of the BYDVSGV and BYDV-RMV were $250 \mathrm{bp}$ and 365 bp, respectively.

It was revealed that the CP gene of the BYDV-PAV was $603 \mathrm{bp}$, the CP gene of the CYDV-RPV was $615 \mathrm{bp}$, the partial CP gene of the BYDV-SGV was $250 \mathrm{bp}$, and the BYDV-RMV partial CP gene was $365 \mathrm{bp}$.

The results of multiple nucleic acid comparisons of BYDV-PAV Mardin isolate (MK732034) revealed that this isolate was similar to other isolates at rates ranging from $89.22-95.52 \%$. This isolate was found to be similar to Germany (KY634926) with the highest rate of $95.52 \%$ and to the Netherlands and Pakistan (KY634886 and JQ811489) with the lowest rate of 89.22\%. This isolate was also found to be similar to the regional Turkey-Van isolate (KC900900) by $92.54 \%$. A total of 59 nucleotide changes (corresponding to 9.8\%) were detected which are spread across all of the CP gene of the Mardin BYDV-PAV isolate.

Multiple comparison and phylogenetic trees were not created since there were no standard length sequences stored in the GenBank belonging to partial or complete CP nucleotide sequences of CYDV-RPV, BYDV-SGV, and BYDV-RMV. Multiple comparison and phylogenetic tree was created only for BYDV-PAV isolate. According to the phylogenetic tree generated with 19 different homologous sequences of BYDV-PAV, Mardin PAV sequence (MK732034) was clustered with Germany isolate (KY634926) isolated from the corn, 
supported by a high bootstrap value (Figure 3). Accordingly, it has been determined that host and geographic affinities are not effective in forming groups of viruses.

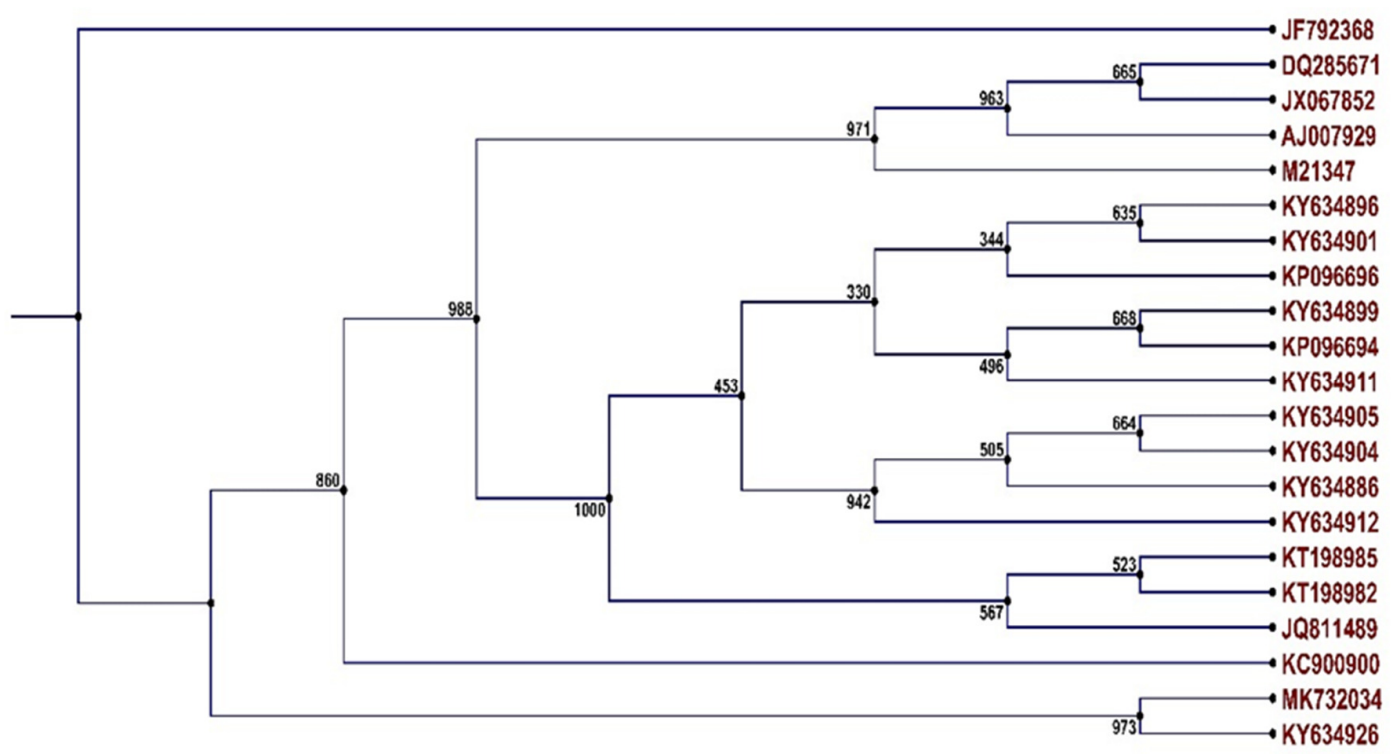

Figure 3. Phylogenetic tree created by Neighbor-joining method with 1000 repeats of the nucleic belonging sequence of the complete coat protein gene of the PAV isolates registered in the NCBI gene bank with the BYDV-PAV (MK732034) isolate. KY634886, (Netherlands) (Lolium multiflorum); JX067852, (Triticum aestivum) (Brazil); DQ285671 (-) (USA); AJ007929, (-) (France); KY634901 (Hordeum vulgare) (France); JQ811489 (Zea mays) (Pakistan); KY634899 (Hordeum vulgare) (China); KY634904 (Hordeum vulgare) (England); KT198985 (Triticum aestivum) (Pakistan); KT198982 (Hordeum vulgare) (Pakistan); KY634912 (Triticum aestivum) (Sweden); KY634926 (Zea mays) (Germany); KY634896 (Triticum aestivum) (Germany); KY634905 (Avena sativa) (Germany); KY634911 (Hordeum vulgare) (Czech Republic); KP096696 (Triticum aestivum) (Hungary); KP096694 (Triticum aestivum) (China); M21347 (-) (Australia); MK732034 (Triticum aestivum) (This Study, Turkey); KC900900 ( Triticum aestivum) (Turkey)

\section{Discussion}

B/CYDVs are the most important virus diseases seen in all cereal production fields worldwide, causing 15-25\% yield losses in wheat, barley, and oats (Lister and Ranieri, 1995). Wheat viruses have a wide range of hosts, and infect not only cereals but also weeds and more than 150 species of meadow, pasture, and grass crops (Gould ve Shaw 1983; İlbağı et al., 2014).

This study evaluated the prevalence of Barley yellow dwarf viruses in wheat plants in Mardin province located in the Southeastern Anatolia Region. Molecular tests revealed at varying rates the presence of BYDVPAV, BYDV-SGV, CYDV-RPV, and BYDV-RMV viruses in five regions (Kiziltepe, Derik, Artuklu, Nusaybin, and Savur) except Dargeçit and Midyat. The current study in Mardin province is the first survey reporting of the mentioned viruses following the study by Hassan et al. (2018) conducted in the South Eastern Anatolia region.

Typical viral infection symptoms, such as redness of flag leaves, dwarfing, and chlorotic stripe patterns on leaves, observed in wheat plants in Mardin province showed consistency with those symptoms recorded by various researchers (Chay et al., 1996; İlbağı et al., 2005). 
There are 9 species of yellow dwarf viruses (İlbağı, 2017). Numerous studies carried out in Turkey recorded that BYDV-PAV, BYDV-SGV, and CYDV-RPV are common viruses at various hosts (İlbaği et al., 2008; Hamamc1, 2012; Aydın, 2017).

BYDV-PAV is highly prevalent in Turkey and all over the world, as identified in the current study (2.5\%). (Kumari et al., 2006; Parizoto et al., 2013; Adhikari et al., 2020). The presence of the second common virus, CYDV-RPV (0.5\%), has been previously reported at rates ranging up to 17.73 in Turkey (Aydın, 2017; Usta et al., 2020). Mix infection of B/CYDVs is a common picture worldwide (Conti et al., 1990; El-Yamani ve Hill, 1990; Deligöz et al., 2011). In this study, it was revealed that PAV+RPV (0.25) and PAV+SGV $(1.75 \%)$ mix infections were at low frequency. Mix infections have also been reported in various regions from Turkey (Hassan et al., 2018; Usta et al., 2020).

According to molecular tests, BYDV-MAV infection was not found in Mardin province, in correlation with those surveyed in the Eastern Anatolia Region (10 provinces) with 900 wheat samples by Usta et al. (2020) and in Samsun province with 184 samples Toksöz ve Yllmaz (2016). However, the occurrence of BYDV-MAV has been confirmed at varying proportions $(25 \%, 2.14 \%$, and $2 \%)$ in surveys conducted by Köklü (2004), İlbağ 1 (2017), Erkan and Yllmaz (2009) in Turkey.

The lowest virus infection in wheat $(0.25 \%, 1$ sample) was recorded for BYDV-RMV. This virus, which is one of the most important pathogens of corn, has been reported to be an important host for barley, oats, triticale, bird meal and various weeds besides wheat (Pocsai et al., 2003; İlbağı and Çıtır, 2014). This viral infection is thought to be due to the fact that corn farming in the region creates a suitable habitat for the vector of this virus (Rhapalosphum maidis) (Siddiqui et al., 2011). overall infection incidences obtained in this study, which was conducted for the first time in the province of Mardin in the Southeastern Anatolia region, were similar to the results of the study conducted by Hassan et al. (2018).

The CP gene sequences of Mardin isolates were recorded in the NCBI gene bank with access numbers MK732034 (603 nt) for BYDV-PAV, MK940529 (250 nt) for BYDV-SGV, MK955886 (365 nt) for BYDVRMV and MK732035 (615 nt) for CYDV-RPV. It has been demonstrated that the CP gene of BYDV-PAV Mardin isolate is 603 bp long as in other isolates in the world, but with 59 base changes. It is thought that BYDV-PAV genome located in the genus luteovirus in the luteoviridae family does not have an ORF-0 region (which acts as an RNA silencer) in the CP gene, causing a high rate of nucleotide substitution (Mangwende et al., 2009; Peter et al., 2009). Another hypothesis is the possibility of new species developing from B/CYDV species (Robertson and French, 2007; Svanella-Dumas et al., 2013). It has been reported that there is a high degree of genetic diversity in RNA genome plant viruses such as B/CYDV due to high recombination, mutation, rapid replication, and large population size (Chare and Holmes, 2006; Sanjuán et al., 2010). In addition, Wu et al. (2011) emphasised that BYDV-PAV is predisposed to divergent strains due to high homologous recombination. They examined the molecular evolution and recombination rates in genomes of BYDV-PAV isolates of different geographic origin and reported at least 22 recombination events involving multiple ORFs in only 58 genomes. These results are in line with the high rate of nucleotide substitution in our study.

The infection rate (3\%) of $\mathrm{B} / \mathrm{CYDV}$ s recognized by this study in Mardin province is not at a level to create an epidemic in wheat agriculture, possibly due to inappropriate agroecosystem conditions. It is uncertain that this advantage will not yield a high yield loss in the future. The main factor affecting the spread of the disease is the presence of at least 25 types of aphids in 15 different genera (Halbert and Voegtlin, 1995). For this reason, it is necessary to pay attention to integrated control strategies by carrying out potential vector scanning in the related region. 


\section{Authors' Contributions}

All authors read and approved the final manuscript.

\section{Acknowledgements}

The study was supported by a grant from The Research Fund of Van Yuzuncu Yil University-YYUBAP (Project no: FYL-2017-6275). The authors acknowledge YYU-BAP for their financial support. This study was a part of the MSc study of Abdulselam KARAOZAN.

\section{Conflict of Interests}

The authors declare that there are no conflicts of interest related to this article.

\section{References}

Adhikari A, Lockhart BE, Ganiger M, Byamukama E, Tande C, Smith MJ, Dill-Macky R (2020). Barley yellow dwarf virus-PAV is the dominant species causing Barley yellow dwarf disease in South Dakota and Minnesota. Crop Protection 134:105171.

Anonim (1996). Türk tarımında buğdayın yeri ve önemi. http://www.ito.org.tr/itoyayin/0022759.pdf. İstanbul Ticaret Odası, İstanbul. Erişim tarihi: 01.02.2016.

Áy Z, Kerényi Z, Takács A, Papp M, Petróczi IM, Gáborjányi R, ... Kertész Z (2008). Detection of cereal viruses in wheat (Triticum aestivum L.) by serological and molecular methods. Cereal Research Communications 36(2):215-224. https://doi.org/10.1556/CRC.36.2008.2.2

Aydın Ö (2017). Determinatin of Barley yellow dwarf virus (BYDVs)'es in rice paddies in the Trakya region of Turkey. Namık Kemal University, Institute of Natural and Applied Scinces, MSc. Thesis.

Bakardjieva N, Krasteva C, Habekuss A, Rabenstein F (2006). Detection of cereal viruses and study of aphid population in Bulgaria. Institute of Plant Protection 43:499-501.

Bisnieks M, Kvarnheden A, Sigvald R, Valkonen JPT (2004). Molecular diversity of the coat proteinencoding region of Barley yellow dwarf virus-PAV and Barley yellow dwarf virus-MAV from Latvia and Sweden. Archives of Virology 149:843-853. https://doi.org/10.1007/s00705-003-0242-2

Bora T, Karaca I (1970). Kültür bitkilerinde hastalığın ve zararın ölçülmesi. EGE Üniv. Matb. No: 167, Bornova, pp 43. Bukvayova N, Henselova M, Vajcikova V, Kormanova T (2006). Occurence of dwarf virus of winter wheat and barley in several regions of Slovakia during the growing seasons 2001-2004. Plant Soil and Environment 52(9):392-401.

Chain F, Riault G, Jacquot E, Trottet M (2006). Field trial of serially passaged isolates of BYDV-PAV overcoming resistance derived from Thinopyrum intermedium in wheat. Plant Breeding 125(3):211-216. https://doi.org/10.1111/j.1439-0523.2006.01210.x

Chare ER, Holmes EC (2006). A phylogenetic survey of recombination frequency in plant RNA viruses. Archives of Virology 151(5):933-946. https://doi.org/10.1007/s00705-005-0675-x

Chay CA, Smith DM, Vaughan R, Gray SM (1996). Diversity among isolates within the PAV serotype of Barley yellow dwarf virus. Phytopathology 86:370-377.

Conti MC, D'Arcy CJ, Jedlinski H, Burnett PA (1990). The "Yellow Plague" of cereals, barley yellow dwarf. In: World Perspectives on Barley Yellow Dwarf. Burnett PA (Eds). CIMMYT, Mexico City D.F. pp 1-6.

Deb M, Anderson JM (2008). Development of a multiplexed PCR detection method for Barley and cereal yellow dwarf viruses, wheat spindle streak virus, wheat streak mosaic virus and Soil-borne wheat mosaic virus. Journal of Virological Methods 148:17-24. https://doi.org/10.1016/j.jviromet.2007.10.015

Deligöz İ, Caner Kahveci Y, Akyol H (2011). Preliminary investigations of Barley yellow dwarf virus-PAV and Barley yellow dwarf virus-MAV in wheat fields of Samsun and Amasya Provinces in Turkey. Bitki Koruma Bülteni 51(2):187-193. 
Domier LL (2012). Family Luteoviridae. In: King AMQ, Adams MJ, Carstens EB, Lefkowitz EJ (Eds). Virus taxonomy. $9^{\text {th }}$ Report of the International Committee on Taxonomy of Viruses. Elsevier/Academic Press. Oxford, UK: pp 1045-1053.

Domier LL (2008). Barley yellow dwarf viruses. Encyclopedia of Virology 3:279-286. https://naldc.nal.usda.gov/download/37366/PDF

El-Muadhidi MA, Makkouk KM, Kumari SG, Jerjess M, Murad SS, Mustafa RR, Tarik F (2001). Survey for legume and cereal viruses in Iraq. Phytopathologia Mediterranea 40(3):224-233.

El-Yamani M, Hill JH (1990). Identification and importance of Barley yellow dwarf virus in Morocco. Plant Disease 74:291-294. https://doi.org/10.1094/PD-74-0291

Erkan E, Yilmaz NDK (2009). Determination of virus diseases on wheat growing areas of Samsun Province. Anadolu Tarım Bilimleri Dergisi 24(2): 67-75.

FAO (2018). Preliminary data now available for selected countries an products. Erişim Tarihi. Retrieved 2018 March 03 from http://www.fao.org/statistics/en/

Foissac L, Gentit P, Svanetia-Dumas L, Dulucq MJ, Candresse T (2001). Polyvalent detection of fruit tree tricho, capillo, and foveaviruses by nested RT-PCR using degenerated and inosine-containing primers (PDO RT-PCR). Acta Horticulturae 550:37-43. https://doi.org/10.17660/ActaHortic.2001.550.2

Gould FW, Shaw RB (1983). Grass systematics. Brittonia 35(3):301-301.

Gray SM, Chapin JW, Smith DM, Banerjee N, Thomas JS (1998). Barley yellow dwarfluteoviruses and their predominant aphid vectors in winter wheat grown in South Carolina. Plant Disease 82:1328-1333. https://doi.org/10.1094/PDIS.1998.82.12.1328

Halbert SE, Connelly BJ, Lister RM, Klein RE, Bishop GW (1992). Vector specificity of Barley yellow dwarf virus serotypes and variants in southwestern Idaho. Annals of Applied Biology 121(1):123-132. https://doi.org/10.1111/j.1744-7348.1992.tb03992.x

Hamamc1 G (2012). Investigations on the determination of some bread wheat (Triticum aestivum L.) cultivar reactions against prevailing virus diseases in Tekirdag provinces in Turkey. Namık Kemal University, Institute of Natural And Applied Scinces, MSc. Thesis

Hamdi I, Najar A, Ghanem HB, Varsani A, Jemmali A (2020). First report of Barley yellow dwarf virus in maize in Tunisia. Journal of Plant Pathology 102:227. https://doi.org/10.1007/s42161-019-00364-W

Hassan NO, Usta M, Al-Maaroof EM, Güller A (2018). The incidence of Barley yellow dwarf viruses (BYDVs) in wheat crops in Diyarbakir (Turkey) and sequence characterization of BYDV-PAV. YYU Journal of Agricultural Science 28: $140-149$.

Hogenhout SA, Ammar D, Whitfield AE, Redinbaugh, MG (2008). Insect vector interactions with persistently transmitted viruses. Annual Review of Phytopathology 46:327-359. https://doi.org/10.1146/annurev.phyto.022508.092135

İlbağ 1 H, Çıtır A, Yorgancı Ü (2005). Occurrence of virus infections on cereal crops and their identifications in the Trakya region of Turkey. Zeitschrift für Pflanzenkrankheiten und Pflanzenschutz / Journal of Plant Diseases and Protection 112:313-320.

İlbağı H, Çıtır A, Kara A, Uysal M (2014). First report of new weed host species Juncus compressus and Geranium dissectum for Barley yellow dwarf virus-PA Vand Barley yellow dwarf virus-MAV on cereals in the Trakya Region of Turkey. Proceedings of The Fifth Plant Protection Congress of Turkey, 3-5 February, Antalya pp 281.

Ilbağ 1 H, Çıtır A, Kara A, Uysal M, Azzouz Olden F (2019). First Report of BYDVs on dicotyledonous weeds in Turkey. Cereal Research Communications 47(2):292-303. https://doi.org/10.1556/0806.47.2019.15

İlbağ 1 H, Pocsai E, Çıtır A, Muranyı I, Vida G, Korkut ZK (2003). Results of two years study on incidence of Barley yellow dwarf viruses, cereal yellow dwarf virus RPV and wheat dwarf virus in Turkey. 3rd International Plant Protection Symposium at Debrecen University, 15-16 October, Debrecen-Hungary, pp 53-63.

İlbağ $1 \mathrm{H}$ (2017). Epidemic of yellow dwarf virus diseases in cereal growing areas and their control. Bitki Koruma Bülteni 57(3):317-335. https://doi.org/10.16955/bitkorb.300020

İlbağı H, Rabenstein F, Habekuss A, Ordon F, Çıtır A, Cebeci O, Budak H (2008). Molecular, serological and aphid transmission studies of Barley yellow dwarf virus-PAV and cereal yellow dwarf virus-RPV in canary seed (Phalaris canariensis L.). Cereal Research Communications 36:225-234.

Kendall DA, George S, Smith BD (1996). Occurrence of Barley yellow dwarf viruses in some common grasses (Gramineae) in south west England. Plant Pathology 45(1):29-37. https://doi.org/10.1046/j.1365-3059.1996.d01-98.X 
Köklü G (2004). Occurrence of cereal viruses on wheat in Tekirdag, Turkey. Phytoprotection 85:19- 25. https://doi.org/10.7202/008902ar

Krueger EN, Beckett R, Gray SM, Miller WA (2013). The complete nucleotide sequence of the genome of Barley yellow dwarf virus-RMV reveals it to be a new Polerovirus distantly related to other yellow dwarf viruses. Frontiers Microbiology 4:205. https://doi.org/10.3389/fmicb.2013.00205

Kumari SG, Muharram I, Makkouk KM, Al-Ansi A, El-Pasha RWA, Al-Motwkel WA, Kassem AH (2006). Identification of viral diseases affecting barley and bread wheat crops in Yemen. Australasian Plant Pathology 35(5):563-568.

Kün E (1996). Tahıllar-I (Serin iklim Tahılları). Ankara Üniversitesi, Ziraat Fakültesi Yayınları, Yayın No: 1451, Ankara.

Lister MR, Ranieri R (1995). Distribution and economic importance of Barley yellow dwarf. In: D'Arcy CJ, Burnett PA (Eds.). Barley yellow dwarf: 40 years of progress. APS Press, MN. pp 29-53.

Malmstrom CM, Shu R (2004). Multiplexed RT-PCR for streamlined detection and separation of barley and cereal yellow dwarf viruses. Journal of Virological Methods 120:69-78. https://doi.org/10.1016/j.jviromet.2004.04.005

Mangwende T, Wang ML, Borth W, Hu J, Moore PH, Mirkov ET, Albert HH (2009). The P0 gene of Sugarcane yellow leaf virus encodesan RNA silencing suppressor with unique activities. Virology 384:38-50. https://doi.org/10.1016/j.virol.2008.10.034

Nancarrow N, Constable FE, Finlay KJ, Freeman AJ, Rodoni BC, Trebicki P, ... Luck JE (2014). The effect of elevated temperature on Barley yellow dwarf virus-PAV in wheat. Virus Research 186:97-103. https://doi.org/10.1016/j.virusres.2013.12.023

Oswald JW, Houston BR (1951). A new virus disease of cereals, transmissible by aphids. Plant Disease Reports 35:471475.

Pakdel A, Afsharifar A, Niazi A, Almasi R, Izadpanah K (2010). Distribution of cereal luteoviruses and molecular diversity of BYDV-PAV isolates in Central and Southern Iran: Proposal of a new species in the genus Luteovirus. Journal of Phytopathology 158:357-364. https://doi.org/10.1111/j.1439-0434.2009.01625.x

Parizoto G, Rebonatto A, Schons J, Lau D (2013). Barley yellow dwarf virus-PAV in Brazil: Seasonal fluctuation and biological characteristics. Tropical Plant Pathology 38(1):11-19. https://doi.org/10.1590/S198256762013000100002

Peter KA, Gildow F, Palukaitis P, Gray SM (2009). The C terminus of the Polerovirus P5 readthrough domain limits virus infection to the phloem. Journal of Virology 83:5419-5429. https://doi.org/10.1128/JVI.02312-08

Pocsai E, Çıtır A, İlbağı H, Köklü G, Muranyi I, Vida G, Korkut ZK (2003). Incidence of Barley yellow dwarf viruses, cereal yellow dwarf virus and wheat dwarf virus in cereal growing areas of Turkey. ournal for Agricultural Sciences 11:583-591.

Pokorny R (2006). Occurrence of viruses of the family Luteoviridae on maize and some annual weed grasses in the Czech Republic. Cereal Research Communications 34(2-3):1087-1092. https://doi.org/10.1556/CRC.34.2006.23.242

Rastgou M, Khatabi B, Kvarnheden A, Izadpanah K (2005). Relationships of Barley yellow dwarf virus-PAV and cereal yellow dwarf virus-RPV from Iran with viruses of the family Luteoviridae. European Journal of Plant Pathology 113(3):321-326. https://doi.org/10.1007/s10658-005-1231-y

Robertson N, French R (2007). Genetic analysis of a novel Alaska Barley yellow dwarf virus in the family Luteoviridae. Archives of Virology 152(2):369-382. https://doi.org10.1007/s00705-006-0846-4

Rybicki EP (2015). A top ten list for economically important plant viruses. Archives of Virology 160(1):17-20. https://doi.org/10.1007/s00705-014-2295-9

Sanjuán R, Nebot MR, Chirico N, Mansky LM, Belshaw R (2010). Viral mutation rates. Journal of Virology 84 (19):97339748. https://doi.org/10.1128/JVI.00694-10

Sathees K (2015). Sequence characterization of Barley yellow dwarf virus-OYV. Sveriges lantbruksuniversitet/Swedish University of Agricultural Sciences. The Faculty of Natural Resources and Agricultural Sciences Department of Plant Biology-Master's programme.

Siddiqui NN, Ilyas M, Mansoor S, Azhar A, Saeed M (2011). Cloning and phylogenetic analysis of coat protein of Barley yellow dwarf virus 1solates from different regions of Pakistan. Journal of Phytopathology 160(1):13-18. Htpps://doi.org/10.1111/j.1439-0434.2011.01853.x

Svanella-Dumas L, Candresse T, Hulle M, Marais A (2013). Distribution of Barley yellow dwarf virus-PAV in the subAntarctic Kerguelen Islands and characterization of two new Luteovirus species. PloS One 8(6):e67231. https://doi.org/10.1371/journal.pone.0067231 
Tao Y, Man J, DevWu Y (2012). Development of a multiplex polymerase chain reaction for simultaneous detection of wheat viruses and a phytoplasma in China. Archives of Virology 157:1261-1267.

Toksöz Y, Y1lmaz NDK (2016). Determination of viruses causing infection in corn (Zea mays L.) fields in Samsun province. Anadolu Tarım Bilimleri Dergisi 31(2):199-206.

TUIK (2018). Agricultural product statistics. Retrieved 2018 march 09 from http://www.tuik.gov.tr/Gosterge.do?

Usta M, Sipahioglu HM, Guller A (2020). Incidence and molecular characterisation of viruses infecting wheat in Eastern Anatolia (Turkey). Fresenius Environmental Bulletin 29(9):7257-7266.

Uzunoğulları N, Gümüş M (2017). Historical development and current state of virus taxanomy. Bahçe 46(2):51-57.

Wu B, Blanchard-Letort A, Liu Y, Zhou G, Wang X, Santiago F, Elena SF (2011). Dynamics of molecular evolution and phylogeography of Barley yellow dwarf virus- PAV. PLoS One 6(2):e16896. https://doi.org/10.1371/journal.pone.0016896

OPEN ACCES

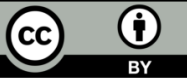

The journal offers free, immediate, and unrestricted access to peer-reviewed research and scholarly work. Users are allowed to read, download, copy, distribute, print, search, or link to the full texts of the articles, or use them for any other lawful purpose, without asking prior permission from the publisher or the author.

License - Articles published in Notulae Botanicae Horti Agrobotanici Cluj-Napoca are Open-Access, distributed under the terms and conditions of the Creative Commons Attribution (CC BY 4.0) License.

(c) Articles by the authors; UASVM, Cluj-Napoca, Romania. The journal allows the author(s) to hold the copyright/to retain publishing rights without restriction. 